\title{
Parkinson's disease: animal models and dopaminergic cell vulnerability
}

\section{Javier Blesa* and Serge Przedborski}

Department of Pathology and Cell Biology, Center for Motor Neuron Biology and Disease, College of Physicians and Surgeons, Columbia University, New York, NY, USA

\author{
Edited by: \\ Jose L. Lanciego, University of \\ Navarra, Spain \\ Reviewed by: \\ Jose L. Lanciego, University of \\ Navarra, Spain \\ Micaela Morelli, University of Cagliari, \\ Italy \\ Lydia Kerkerian-Le Goff, Centre \\ National de la Recherche \\ Scientifique/Aix-Marseille University, \\ France

\section{*Correspondence:} \\ Javier Blesa, Department of \\ Pathology and Cell Biology, Center for \\ Motor Neuron Biology and Disease, \\ College of Physicians and Surgeons, \\ Columbia University, 630 West 168th \\ Street, Room 4-401, New York, \\ NY 10032, USA \\ e-mail: javiblesa@hotmail.com
}

Parkinson's disease (PD) is a neurodegenerative disorder that affects about $1.5 \%$ of the global population over 65 years of age. A hallmark feature of PD is the degeneration of the dopamine (DA) neurons in the substantia nigra pars compacta (SNc) and the consequent striatal DA deficiency. Yet, the pathogenesis of PD remains unclear. Despite tremendous growth in recent years in our knowledge of the molecular basis of PD and the molecular pathways of cell death, important questions remain, such as: (1) why are SNc cells especially vulnerable; (2) which mechanisms underlie progressive SNc cell loss; and (3) what do Lewy bodies or $\alpha$-synuclein reveal about disease progression. Understanding the variable vulnerability of the dopaminergic neurons from the midbrain and the mechanisms whereby pathology becomes widespread are some of the primary objectives of research in PD. Animal models are the best tools to study the pathogenesis of PD. The identification of PD-related genes has led to the development of genetic PD models as an alternative to the classical toxin-based ones, but does the dopaminergic neuronal loss in actual animal models adequately recapitulate that of the human disease? The selection of a particular animal model is very important for the specific goals of the different experiments. In this review, we provide a summary of our current knowledge about the different in vivo models of PD that are used in relation to the vulnerability of the dopaminergic neurons in the midbrain in the pathogenesis of PD.

Keywords: MPTP, 6-OHDA, rotenone, synuclein, LRRK2, parkin, DJ1, ATP13A2

\section{INTRODUCTION}

Parkinson's disease $(\mathrm{PD})$ is a common neurodegenerative disorder whose prevalence increases with age (Pringsheim et al., 2014). The cardinal features of PD include tremor, rigidity and slowness of movements, albeit non-motor manifestations such as depression and sleep disturbances are increasingly recognized in these patients (Rodriguez-Oroz et al., 2009). Over the past decade, more attention has also been paid to the broader nature of the neurodegenerative changes in the brains of PD patients. Indeed, for many years, the neuropathological focus has been on the striking neurodegeneration of the nigrostriatal dopaminergic pathway, however, nowadays, disturbances of the serotonergic, noradrenergic, glutamatergic, GABAergic, and cholinergic systems (Brichta et al., 2013) as well as alterations in neural circuits are now being intensively investigated from the angle of the pathophysiology of PD (Obeso et al., 2014), with the underlying expectation of acquiring a better understanding of the neurobiology of this disabling disorder and of identifying new targets for therapeutic purposes. From a molecular biology point of view, the accepted opinion that the PD neurodegenerative process affects much more than the dopaminergic neurons of the substantia nigra pars compacta $(\mathrm{SNc})$, has triggered a set of fascinating questions such as: are dopaminergic and non-dopaminergic neurons in PD dying by the same pathogenic mechanisms; and, given the fact that within a given subtype of neurons, not all die to the same extent nor at the same rate [e.g., dopaminergic neurons in the $\mathrm{SNc}$ vs. ventral tegmental area (VTA)], what are the molecular determinants of susceptibly/and resistance to disease?

To gain insights into these types of critical questions, a brief review of the literature demonstrates that the enthusiasm for experimental models of $\mathrm{PD}$, both in vitro and in vivo, has greatly increased, in part, thanks to new strategies for producing sophisticated models, such as the temporal- and/or cell-specific expression of mutated genes in mice (Dawson et al., 2010), human pluripotent cells coaxed into a specific type of neurons (Berg et al., 2014), and a host of invertebrate organisms like Drosophila (Guo, 2012), Caenorhabditis elegans (Chege and McColl, 2014), or Medaka fish (Matsui et al., 2014). Thus far, however, all of these experimental models continue to be categorized into two main flavors: toxic and genetic (and sometimes, both approaches are combined). But, more importantly, none of the currently available models phenocopy PD, mainly because they lack some specific neuropathological and/or behavioral feature of PD. Some PD experts see this as fatal flaws, while others tend to ignore the shortcomings. It has always been our personal view that models are just models and, as such, given the large collection of models the field of PD possesses, the prerequisite resides in not using just any model but in selecting the optimal in vitro or in vivo model whose strengths are appropriate for investigating the question being asked and whose weaknesses will not invalidate the interpretation of an experiment.

Based on our above premise, herein, we discuss the experimental models of PD, with a deliberate emphasis on in vivo mammalian 
Table 1 | Animal models of Parkinson disease.

\begin{tabular}{|c|c|c|c|c|c|}
\hline & Animal model & Motor behavior & SNc neuron loss & Striatal DA loss & $\begin{array}{l}\text { Lewy body/Syn } \\
\text { pathology }\end{array}$ \\
\hline \multirow[t]{5}{*}{ Toxin-based } & MPTP Mice & Reduced locomotion, bradykinesia & $\uparrow \uparrow \uparrow$ & $\uparrow \uparrow \uparrow$ & NO \\
\hline & MPTP Monkeys & $\begin{array}{l}\text { Reduced locomotion, altered behavior, } \\
\text { tremor, and rigidity }\end{array}$ & $\uparrow \uparrow \uparrow$ & $\uparrow \uparrow \uparrow$ & NO \\
\hline & 6-OHDA rat & Reduced locomotion, altered behavior & $\uparrow \uparrow \uparrow$ & $\uparrow \uparrow \uparrow$ & NO \\
\hline & Paraquat/maneb & Reduced locomotion & $\uparrow \uparrow$ & $\uparrow \uparrow \uparrow$ & YES \\
\hline & MET/MDMA & Reduced locomotion & $\uparrow \uparrow$ & $\uparrow \uparrow \uparrow$ & NO \\
\hline \multirow[t]{3}{*}{ Genetic mutations* } & $\alpha$-Synuclein & $\begin{array}{l}\text { Altered behavior, reduced or increased } \\
\text { motor activity }\end{array}$ & $\uparrow$ Not consistent & $\uparrow$ & $\uparrow$ (in old animals) \\
\hline & DJ-1 & Decreased locomotor activity & NO & NO & NO \\
\hline & ATP13A2 & Late onset sensorimotor deficits & NO & NO & NO \\
\hline \multirow[t]{6}{*}{ Others } & $\mathrm{SHH}$ & Reduced locomotion & $\uparrow \uparrow$ & $\uparrow \uparrow$ & NO \\
\hline & Nurr1 & Reduced locomotion & $\uparrow \uparrow$ & $\uparrow \uparrow$ & NO \\
\hline & Engrailed 1 & Reduced locomotion & $\uparrow \uparrow$ & $\uparrow$ & NO \\
\hline & Pitx3 & Reduced locomotion & $\uparrow \uparrow \uparrow$ & $\uparrow \uparrow \uparrow$ & NO \\
\hline & C-Rel-NFKB & Gait, bradykinesia, rigidity & $\uparrow \uparrow$ & $\uparrow \uparrow$ & YES \\
\hline & MitoPark & Reduced locomotion, tremor, and rigidity & $\uparrow \uparrow$ & $\uparrow \uparrow$ & YES \\
\hline
\end{tabular}

$\uparrow \uparrow \uparrow$, Severe loss; $\uparrow \uparrow$, Moderate loss; $\uparrow$, Mild loss.

*This table summarizes general observations for each model. See the main text for full and specific description of different animal models for each genetic mutation.

models induced by reproducible means. Over the years, a constellation of uncommon strategies and organisms have been used to produce models of PD. However, in this review, we have decided not to discuss these cases, because we have limited space and because we are missing sufficient independent information to assessment the reproducibility and reliability of these models, which, to us, is critical for distinguishing between interesting "case reports" and useful tools to model human diseases.

\section{TOXIN MODELS}

A number of pharmacological and toxic agents including reserpine, haloperidol, and inflammogens like lipopolysaccharide have been used over the years to model PD, although the two most widely used are still the classical 6-OHDA in rats and MPTP in mice and monkeys. Although the neurotoxic models appear to be the best ones for testing degeneration of the nigrostriatal pathway, some striking departures from PD need to be mentioned: the degeneration of dopaminergic neurons progress rapidly, i.e., days not years, lesions are primarily if not exclusively dopaminergic, and animals lack the typical PD proteinaceous inclusions called
Lewy bodies (LBs). In addition, behavioral abnormalities in these animal models are also a challenging question (see below; Table 1).

\section{MPTP}

MPTP is the tool of choice for investigations into the mechanisms involved in the death of DA neurons in PD. MPTP has been shown to be toxic in a large range of species (Tieu, 2011). The most popular species, besides primates, is the mouse, as rats were found to be resistant to this toxin (Chiueh et al., 1984). A number of intoxication regimens or administration methods have been used over the years in mouse (Jackson-Lewis and Przedborski, 2007; Meredith et al., 2008) and in primates (Bezard et al., 1997; Blesa et al., 2012; Porras et al., 2012). In both species, MPTP primarily causes damage to the nigrostriatal DA pathway with a profound loss of DA in the striatum and SNc (Dauer and Przedborski, 2003).

This specific and reproducible neurotoxic effect on the nigrostriatal system is the strength of this model. Neuropathological data show that MPTP administration causes damage to the nigrostriatal DA pathway that is identical to that seen in PD (Langston 
et al., 1983), yet there is a resemblance that goes beyond the loss of SNc DA neurons. Like in PD, MPTP causes greater loss of DA neurons in SNc than in VTA or retrorubral field (Seniuk et al., 1990; Muthane et al., 1994; Blesa et al., 2011, 2012) and, at least in monkeys treated with low doses of MPTP, greater degeneration of DA nerve terminals in the putamen than in the caudate nucleus (Moratalla etal., 1992; Snow et al., 2000; Blesa etal., 2010).

A often raised weakness with this model is the lack of LB (Shimoji et al., 2005; Halliday et al., 2009). Although no LBs have been observed in these models so far, a few reports have investigated the expression, regulation or pattern of $\alpha$-syn after MPTP exposure (Vila et al., 2000; Dauer et al., 2002; Purisai et al., 2005). Only, in MPTP-injected monkeys, have intraneuronal inclusions, reminiscent of LBs, been described (Forno et al., 1986; Kowall et al., 2000). Behavior is also an issue, and except for the monkeys, features reminiscent of $\mathrm{PD}$ are lacking especially in mice. Yet, using a battery of tests, some motor alterations in mice with profound dopaminergic deficit may be detected (Taylor et al., 2010).

\section{6-OHDA}

Like MPTP, 6-OHDA is a selective catecholaminergic neurotoxin that is used, mainly, to generate lesions in the nigrostriatal DA neurons in rats (Ungerstedt, 1968). Since 6-OHDA cannot cross the blood-brain barrier, systemic administration fails to induce parkinsonism. So, this induction model requires that 6-OHDA be injected (typically as a unilateral injection) into the SNc, medial forebrain bundle or striatum (Blandini et al., 2008). Intraventricular administration has also been achieved (Rodríguez Díaz et al., 2001). The effects resemble those in the acute MPTP model, causing neuronal death over a brief time course ( $12 \mathrm{~h}$ to $2-3$ days). The intrastriatal injection of 6-OHDA causes progressive retrograde neuronal degeneration in the SNc and VTA (Sauer and Oertel, 1994; Przedborski et al., 1995). The pattern of DA loss in animals bearing a full lesion (>90\%) again mirrors seen that in PD, with the SNc showing more cells loss compared to the VTA (Przedborski et al., 1995). As in PD, DA neurons are killed, and the non-DA neurons are preserved. However, like in the MPTP model, 6-OHDA does not produce LB-like inclusions in the nigrostriatal pathway. Traditionally, behavioral assessments of motor impairments in the unilateral 6-OHDA model are done by drug-induced rotation tests (Dunnett and Lelos, 2010). However, drug-free sensorimotor behavioral tests have been developed in both rat and mice that may be helpful for the preclinical testing of new symptomatic strategies (Schallert et al., 2000; Glajch et al., 2012).

\section{ROTENONE}

Chronic systemic exposure to rotenone in rats causes many features of PD, including nigrostriatal DA degeneration (Betarbet et al., 2000). The rotenone-administered animal model also reproduces all of the behavioral features reminiscent of human PD. Importantly, many of the degenerating neurons have intracellular inclusions that resemble LB morphologically. These inclusions show immunoreactivity for $\alpha$-syn and ubiquitin as did the original LB (Sherer et al., 2003). Usually, rotenone is administered by daily intraperitoneal injection (Cannon et al., 2009), intravenously or subcutaneously (Fleming et al., 2004). Recently, rotenone has been tested in mice through chronic intragastric administration, (Pan-Montojo et al., 2010) or as a stereotaxic injection or infusion directly in the brain (Alam et al., 2004; Xiong et al., 2009) recapitulating the slow and specific loss of DA neurons. However, administration of rotenone in rats causes high mortality and, somehow, is difficult to replicate.

\section{PARAQUAT/MANEB}

Although the idea that the herbicide paraquat (N,N'-dimethyl4-4-4'-bypiridinium), may cause parkinsonism in humans has attracted some interest, at this time, as pointed out by Berry and collaborators, epidemiological and clinical evidence that paraquat may cause PD is inconclusive (Berry et al., 2010). And, the same view seems to apply to the fungicide maneb (manganese ethylenebisdithiocarbamate; Berry et al., 2010). Moreover, effects of this compound in the nigrostriatal DA system is somewhat ambiguous (Freire and Koifman, 2012). Regarding animal models, some researchers report that, following the systemic application of paraquat, mice exhibit reduced motor activity and a dose-dependent loss of striatal tyrosine hydroxylase $(\mathrm{TH})$ fibers and SNc neurons with relative sparing of the VTA (Brooks et al., 1999; Day et al., 1999; McCormack et al., 2002; Rappold et al., 2011). Like rotenone, paraquat may be useful in the laboratory because of its presumed ability to induce LB in DA neurons (Manning-Bog et al., 2002). Maneb has been shown to decrease locomotor activity and produce SNc neurons loss (Thiruchelvam et al., 2003) and potentiate both the MPTP and the paraquat effects (Takahashi et al., 1989; Thiruchelvam et al., 2000; Bastías-Candia et al., 2013). However, as with rotenone, this model shows contradictory results, variable cell death and loss of striatal DA content (Miller, 2007).

\section{AMPHETAMINE-TYPE PSYCHOSTIMULANTS}

Some amphetamine derivatives such as methamphetamine (METH) and 3,4-methylenedioxymethamphetamine (MDMA) also have neurotoxic effects on the nervous system causing not only functional deficits but also structural alterations (Cadet et al., 2007; Thrash et al., 2009). The first study to show DA depletion in rats following repeated, high-dose exposure to METH was conducted by Kogan etal. (1976). Hess etal. (1990) and Sonsalla et al. (1996) showed that high-dose treatment with METH in mice resulted in a loss of DA cells in the SNc. Since then, several studies have reported selective DA or serotonergic nerve terminal as well as $\mathrm{SNc}$ neuronal loss in rodents, primates or even guinea pig following the administration of very high doses of METH (Wagner et al., 1979; Trulson et al., 1985; Howard et al., 2011; Morrow et al., 2011).

3,4-Methylenedioxymethamphetamine can also elicit significant neurobehavioral adverse effects. Although MDMA toxicity mainly affects the serotonergic system, DA system can also be affected to a lesser extent (Jensen et al., 1993; Capela et al., 2009). In mice, repeated administration of MDMA produces degeneration of DA terminals in the striatum (O'Callaghan and Miller, 1994; Granado et al., 2008a,b) and TH+ neuronal loss in the SNc (Granado et al., 2008b).

Exposure to low concentrations of METH results in a decrease of the vulnerability of the SNc DA cells to toxins like 6-OHDA or 
MPTP (Sziráki et al., 1994; El Ayadi and Zigmond, 2011). On the other hand, chronic exposure to MDMA of adolescent mice exacerbates DA neurotoxicity elicited by MPTP in the SNc and striatum at adulthood (Costa et al., 2013). Hence, a METH or MDMAtreated animal model could be useful to study the mechanisms of DA neurodegeneration (Thrash et al., 2009).

\section{GENETIC MODELS}

Genetic models may better simulate the mechanisms underlying the genetic forms of PD, even though their pathological and behavioral phenotypes are often quite different from the human condition. A number of cellular and molecular dysfunctions have been shown to result from these gene defects like fragmented and dysfunctional mitochondria (Exner et al., 2012; Matsui et al., 2014; Morais et al., 2014), altered mitophagy (Lachenmayer and Yue, 2012; Zhang et al., 2014), ubiquitin-proteasome dysfunction (Dantuma and Bott, 2014), and altered reactive oxygen species production and calcium handling (Gandhi et al., 2009; Joselin et al., 2012; Ottolini et al., 2013). Some studies have reported alterations in motor function and behavior in these mice (Hinkle et al., 2012; Hennis et al., 2013; Vincow et al., 2013), and sensitivities to complex I toxins, like MPTP, different from wild type (WT) mice (Dauer et al., 2002; Nieto et al., 2006; Haque et al., 2012) although this latter finding is not always consistent (Rathke-Hartlieb et al., 2001; Dong et al., 2002). However, almost all of the studies evaluating the integrity of the nigrostriatal DA system in these genetic models failed to find significant loss of DA neurons (Goldberg et al., 2003; Andres-Mateos et al., 2007; Hinkle et al., 2012; Sanchez et al., 2014). Thus, recapitulation of the genetic alterations in mice is insufficient to reproduce the final neuropathological feature of PD. Below, we describe transgenic mice or rat models which recapitulate the most known mutations observed in familial PD patients (Table 1).

\section{$\alpha$-SYNUCLEIN}

$\alpha$-syn was the first gene linked to a dominant-type, familial PD, called Park1, and is the main component of LB which are observed in the PD brain (Goedert et al., 2013). Three missense mutations of $\alpha$-syn, encoding the substitutions A30P, A53T, and E46K, have been identified in familial PD so far (Vekrellis et al., 2011; Schapira et al., 2014). Furthermore, the duplication or triplication of $\alpha$-syn is sufficient to cause PD, suggesting that the level of $\alpha$-syn expression is a critical determinant of PD progression (Singleton et al., 2003; Kara et al., 2014).

To date, various $\alpha$-syn transgenic mice have been developed. Although, in some of these mice, decreased striatal levels of TH or DA and behavioral impairments indicate that the accumulation of $\alpha$-syn can significantly alter the functioning of DA neurons, no significant nigrostriatal degeneration has been found in most of them. The models of $\alpha$-syn overexpression in mice recapitulate the neurodegeneration, depending primarily on the promoter used to drive the expression of the transgene, whether the transgene codes for the WT or the mutated protein, and the level of expression.

Although a lot of behavioral alterations have been described in both the A30P and A53T mice (Sotiriou et al., 2010; Oaks et al., 2013; Paumier etal., 2013), the mouse prion protein promoter failed to reproduce the cell loss in the $\mathrm{SNc}$ or locus coeruleus (LC; van der Putten et al., 2000; Giasson et al., 2002; Gispert et al., 2003). The same phenotype was found with the hamster prion promoter (Gomez-Isla et al., 2003). Mice based on the PDGF- $\beta$ promoter showed loss of terminals and DA in the striatum but no $\mathrm{TH}+$ cell loss (Masliah et al., 2000). The TH promoter led to TH+ cell loss only in a few studies (Thiruchelvam et al., 2004; Wakamatsu et al., 2008) but did not replicate the $\alpha$-syn neuropathology as did the Thy-1 promoter (Matsuoka et al., 2001; Chen et al., 2006; Miller etal., 2007; Su etal., 2009). However, the use of the murine Thy-1 promoter often causes loss of DA levels in the striatum but only moderate nigral DA cell loss in the SNc, with $\alpha$-syn pathology (van der Putten et al., 2000; Rockenstein et al., 2002; Ikeda et al., 2009; Ono et al., 2009; Lam et al., 2011). A new line of tetracycline-regulated inducible transgenic mice that overexpressed $\alpha$-syn A53T under control of the promoter of Pitx3 in the DA neurons developed profound motor disabilities and robust midbrain neurons neurodegeneration, profound decrease of DA release, the fragmentation of Golgi apparatus, and the impairments of autophagy/lysosome degradation pathways (Lin et al., 2012). Janezic et al. (2013) generated BAC transgenic mice (SNCA-OVX) that express WT human $\alpha$-syn and which display an age-dependent loss of SNc DA neurons preceded by early deficits in DA release from terminals in the dorsal striatum, protein aggregation and reduced firing of SNc DA neurons. Regarding the transgene expressed, the A53T seems to be more effective than the A30P, in general.

Several viral vectors, primarily lentiviruses and adenoassociated viruses (AAVs), have been used to drive exogenous $\alpha$-syn. Rats are usually used for these studies because viral vector delivery requires stereotactic injections within or near the site of the neuronal cell bodies in the SNc (Kirik et al., 2002; Klein et al., 2002; Lo Bianco et al., 2002; Lauwers et al., 2003, 2007). In contrast to all of the $\alpha$-syn transgenic mice, viral vector-mediated $\alpha$-syn models display $\alpha$-syn pathology and clear dopaminergic neurodegeneration. The injection of human WT or A53T mutant $\alpha$-syn by AAVs into the SNc neurons of rats induces a progressive, age-dependent loss of DA neurons, motor impairment, and $\alpha$-syn cytoplasmic inclusions (Kirik et al., 2002; Klein et al., 2002; Lo Bianco et al., 2002; Decressac et al., 2012). This cell loss was preceded by degenerative changes in striatal axons and terminals, and the presence of $\alpha$-syn positive inclusions in axons and dendrites (Kirik et al., 2003; Decressac et al., 2012). These results have been replicated in mice (Lauwers et al., 2003; Oliveras-Salvá et al., 2013). Although these models still suffer from a certain degree of variability, they can be of great value for further development and testing of neuroprotective strategies.

Recently, several studies have demonstrated that $\alpha$-syn may be transmissible from cell to cell (Luk and Lee, 2014). In WT mice, a single intrastriatal inoculation of synthetic $\alpha$-syn fibrils or pathological $\alpha$-syn purified from postmortem PD brains led to the cell-to-cell transmission of pathologic $\alpha$-syn and LB pathology in anatomically interconnected regions and was accompanied by a progressive loss of dopaminergic neurons in the $\mathrm{SNc}$ and reduced DA levels in the striatum, culminating in motor deficits (Luk et al., 2012a,b; Masuda-Suzukake et al., 2014; Recasens et al., 2014). Moreover, the hind limb intramuscular injection of $\alpha$-syn 
can induce pathology in the central nervous system in transgenic mouse models (Sacino et al., 2014).

\section{LRKK2}

Mutations in LRRK2 are known to cause a late-onset autosomal dominant inherited form of PD (Healy et al., 2008). Several mutations have been identified in LRRK2, the most frequent being the G2019S mutation, a point mutation in the kinase domain, whereas $\mathrm{R} 1441 \mathrm{C}$, a mutation in the guanosine triphosphatase domain, is the second most common (Rudenko and Cookson, 2014). Overall, LRRK2 mice models display mild or not functional disruption of the nigrostriatal DA neurons of the SNc.

LRRK2 KO mice are viable and have an intact nigrostriatal DA pathway up to 2 years of age. Neuropathological features associated with neurodegeneration or altered neuronal structure were absent, but $\alpha$-syn or ubiquitin accumulation has been reported in these mice (Andres-Mateos et al., 2009; Lin et al., 2009; Tong et al., 2010; Hinkle et al., 2012). To date, two LRRK2 KO rat models have been developed, although the consequences of LRRK2 deficiency in the brain are still unknown (Baptista et al., 2013; Ness et al., 2013).

Both G2019S and R1441C LRRK2 KI mice are viable, fertile, and appear grossly normal. This mutation had no impact on DA neuron number or morphology in the SNc, or on noradrenergic neurons in the LC. Striatal DA levels and DA turnover are also normal in these mice (Tong et al., 2009; Herzig et al., 2011).

Overexpression of G2019S LRRK2 leads to a mild progressive and selective degeneration of SNc DA neurons (20\%) up to 2 years of age. Furthermore, no alteration in striatal DA levels or locomotor activity could be detected in older G2019S LRRK2 mice (Ramonet et al., 2011; Chen et al., 2012). Also, Maekawa et al. (2012) generated transgenic mice constitutively expressing V5-tagged human I2020T LRRK2 from a CMV promoter with no influence on SNc DA neuronal number or striatal DA fiber density. Zhou etal. (2011) developed a transgenic rat model expressing G2019S LRRK2. Despite a mild behavioral alteration, LRRK2 expression had no effect on the number of DA neurons or on striatal DA content. Recently, conditional expression of R1441C LRRK2 in midbrain dopaminergic neurons of mice results in nuclear abnormalities but, without neurodegeneration (Tsika et al., 2014).

Additional LRRK2 BAC transgenic mouse models have also been developed. These mice displayed age-dependent and progressive motor deficits at 10-12 months of age, accompanied by a mild reduction of striatal DA release. Adult neurogenesis and neurite outgrowth are impaired. No DA neurons loss or degeneration of striatal nerve terminals where observed in mice at 9-10 months of age (Li et al., 2009b, 2010; Melrose et al., 2010; Winner et al., 2011).

Regarding the viral vector-based models, Lee et al. (2010) developed a herpes simplex virus (HSV) amplicon-based mouse model of G2019S LRRK2-induced DA neurotoxicity. The nigrostriatal expression of WT LRRK2 induced modest nigral DA neurodegeneration (10-20\%), whereas expression of the kinase-hyperactive G2019S LRRK2 resulted in a 50\% neuronal loss in the ipsilateral $\mathrm{SNc}$ associated with reduced striatal DA fiber density at 3 weeks post-injection. In another study, a model based on the unilateral injection of recombinant, second-generation human serotype 5 adenoviral (rAd) vectors expressing FLAG-tagged human WT or G2019S LRRK2 driven by a neuronal-specific human synapsin-1 promoter in rats induced the progressive loss (20\%) of DA neurons in the ipsilateral SNc over 42 days, but with no reduction of striatal DA fiber density (Dusonchet et al., 2011).

\section{PINK1}

Mutations in the gene PINK1 cause another form of PD called PARK6 (Scarffe etal., 2014). PINK1 KO mice have an agedependent, moderate reduction in striatal DA levels accompanied by low locomotor activity, but do not exhibit major abnormalities in the DA neurons or striatal DA levels (Gautier et al., 2008; Gispert et al., 2009). These mice showed no LB formation or nigrostriatal degeneration for up to 18 months of age. However, in PINK1 KO mice, overexpression of $\alpha$-syn in the SNc resulted in enhanced dopaminergic neuron degeneration as well as significantly higher levels of $\alpha$-syn phosphorylation at serine 129 at 4 weeks post-injection (Oliveras-Salvá et al., 2014). Recently, a PINK1 null mouse with an exon 4-5 deletion displayed a progressive loss of DA in the striatum, but there was no degeneration in the SNc (Akundi etal., 2011). The phenotypes of these mice are very similar to those of Parkin $\mathrm{KO}$ and $\mathrm{DJ}-1 \mathrm{KO}$ mice.

\section{PARKIN}

Parkin is an E3 ubiquitin ligase that functions in the ubiquitinproteasome system. Mutations in parkin are a cause of familial PD and are also seen in some young-onset sporadic PD cases (Lücking et al., 2000; Periquet et al., 2003). Several parkin KO mice have been generated, typically produced by deletion at exon 3, exon 7, or exon 2 in the PRKN gene (Goldberg et al., 2003; Itier et al., 2003; Palacino et al., 2004; Von Coelln et al., 2004; Perez and Palmiter, 2005; Zhu et al., 2007; Martella et al., 2009). However, they show no substantial DA-related behavioral abnormalities. Some of these KO mice exhibit slightly impaired DA release (Itier et al., 2003; Kitada et al., 2009a) and reduced norepinephrine levels in the olfactory bulb and spinal cord with an abnormal nigrostriatal region but without loss of SNc neurons (Goldberg et al., 2003; Von Coelln et al., 2004).

Only the Parkin-Q311X-DAT-BAC mice exhibit multiple late onsets and progressive hypokinetic motor deficits, age-dependent DA neuron degeneration in the $\mathrm{SNc}$ and a significant reduction in striatal DA and dopaminergic terminals in the striatum (Lu et al., 2009). Recently, overexpression of T240R-parkin and of human WT parkin induced progressive and dose-dependent DA cell death in rats (Van Rompuy et al., 2014).

\section{DJ-1}

DJ-1 mutations are linked to an autosomal recessive, early onset PD (Puschmann, 2013). KO models of DJ-1 mice with a targeted deletion of exon 2 or insertion of a premature stop codon in exon 1 show decreased locomotor activity, a reduction in the release of evoked DA in the striatum but no loss of SNc DA neurons and no change of the DA levels (Goldberg et al., 2005; Kim et al., 2005). However, one line of DJ-1 KO mice shows loss of DA neurons in the VTA (Pham et al., 2010). 
Interestingly, a recently described DJ-1 KO mouse, backcrossed on a C57/BL6 background, displayed a dramatic early onset unilateral loss of DA neurons in the $\mathrm{SNc}$, progressing to bilateral degeneration of the nigrostriatal axis, with aging. In addition, these mice exhibit age-dependent bilateral degeneration in the LC and display, with aging, a mild motor behavioral deficit at specific time points (Rousseaux et al., 2012). Therefore, if confirmed, this new mouse model would provide a tool to study the preclinical aspects of PD.

\section{ATP13A2}

Mutations in ATP13A2 (PARK9), encoding a lysosomal P-type ATPase, are associated with both Kufor-Rakeb syndrome (KRS) and neuronal ceroid lipofuscinosis. KRS has recently been classified as a rare genetic form of PD (Heinzen et al., 2014; Yang and $\mathrm{Xu}, 2014)$. Despite the accumulation of lipofuscin deposits in the SNc and late-onset sensorimotor deficits, there was no change in the number of DA neurons in the SNc or in striatal DA levels in aged Atp13a2 KO mice (Schultheis et al., 2013).

\section{OTHER MODELS}

Inactivation of multiple PD genes has been shown to be insufficient to cause significant nigral degeneration within the lifespan of mice (Hennis et al., 2014). Triple KO mice lacking Parkin, DJ1, or PINK1 have normal morphology and normal numbers of dopaminergic and noradrenergic neurons in the $\mathrm{SNc}$ and LC. Also, levels of striatal DA in these triple $\mathrm{KO}$ mice were normal at 16 months, but increased at 24 months of age (Kitada et al., 2009b).

Sonic hedgehog $(\mathrm{SHH})$, nuclear receptor related protein-1 (Nurr1), pituitary homeobox3 (Pitx3), and engrailed 1 (EN1) are transcription factors important to the development and maintenance of the nigro-striatal system (Jankovic et al., 2005; Jiang et al., 2005; Li et al., 2009a; Gonzalez-Reyes et al., 2012; Zhang etal., 2012). Both SHH and Nurr1 KO mice show a progressive loss of DA neurons without LB formation (Jiang et al., 2005; Kadkhodaei et al., 2009; Gonzalez-Reyes et al., 2012). Also, Pitx3 gene mutations cause a complete loss of SNc and VTA DA neurons and altered locomotor activity in mice (Hwang et al., 2003; van den Munckhof et al., 2003). Recently, engrailed 1 heterozygous mice $($ En $1+/-)$ showed a significant and progressive retrograde degeneration of SNc neurons and dystrophic and swollen striatal TH+ terminals (Nordström et al., 2014). c-Rel (a subunit of the NFKB complex) KO mice also develop a PD-like neuropathology on aging. At 18 months of age, c-rel (-/-) mice exhibit a significant loss of DA neurons in the SNc, loss of dopaminergic terminals and a significant reduction of DA and HVA levels in the striatum. In addition, these mice show age-dependent deficits in locomotor activity and a marked immunoreactivity for fibrillary $\alpha$-syn in the SNc (Baiguera et al., 2012).

Conditional disruption of the gene for mitochondrial transcription factor A in DA neurons (MitoPark) results in a parkinsonism phenotype in mice that includes an adult-onset, slowly progressive impairment of motor function, DA neuron death, degeneration of nigrostriatal pathways and intraneuronal inclusions (Ekstrand et al., 2007; Good et al., 2011). Also, cell-specific deletion of the essential autophagy gene Atg7 in midbrain DA neurons causes DA neuron loss in the SNc at 9 months, accompanied by late-onset locomotor deficits. Atg7-deficient DA neurons in the midbrain also exhibit early dendritic and axonal dystrophy, reduced striatal DA content, and the formation of somatic and dendritic ubiquitinated inclusions (Friedman et al., 2012).

Recently, it has been suggested that a vesicular monoamine tranporter (VMAT2) defect may be an early abnormality promoting mechanisms leading to nigrostriatal DA neuron death in PD (Pifl et al., 2014). VMAT2-deficient mice display a progressive loss of nigral DA and LC cells, loss of striatal DA and $\alpha$-syn accumulation (Taylor et al., 2011, 2014). Neuroprotection from MPTP toxicity in VMAT2-overexpressors and enhanced MPTP toxicity in VMAT2-KO mice suggest that interventions aimed at enhancing vesicular capacity may be of therapeutic benefit in PD (Takahashi et al., 1997; Lohr et al., 2014).

\section{CONCLUDING REMARKS}

Despite the significant contribution of all of these animal models to our understanding of PD, none of these models reproduce the human condition. If we consider toxic models, significant nigrostriatal degeneration is generally obtained with some motor deficits (particularly in MPTP-treated monkeys). Although no consistent LB-like formation is detected, this issue in the study of PD pathogenesis remains to be demonstrated. On the other hand, although transgenic models offer insights into the causes of PD pathogenesis or LB-like formation, the absence of consistent neuronal loss in the SNc remains a major limitation for these models. Another troubling observation in genetic models is the often inconsistent phenotypes among the lines with the same mutations. Whether or not this is related to an artifact of insertion of the transgene or to the actual genetic background, it would be advisable to test these in more than one line.

In addition to the classical motor abnormalities observed in $\mathrm{PD}$, animal models are increasingly used to study non-motor symptoms (sleep disturbances, neuropsychiatric and cognitive deficits; Campos etal., 2013; Drui etal., 2014). Both toxin-based and genetic models are suitable for studying these non-motor symptoms that are increasingly recognized as relevant in disease-state (McDowell and Chesselet, 2012). Toxins-based models have been mostly used to seek the mechanisms involved in levodopa induced dyskinesias (LID) thus far (Morin et al., 2014). However, recently viral vector-mediated silencing of $\mathrm{TH}$ was used to induce striatal DA depletion without affecting the anatomical integrity of the presynaptic terminals and study LID (Ulusoy etal., 2010). And more recently, for the first time, a genetic mouse model overexpressing A53T $\alpha$-syn in nigrostriatal and corticostriatal projection neurons shows involuntary movements and increased post-synaptic sensitivity to apomorphine (Brehm et al., 2014). It seems unlikely that a single model can fully recapitulate the complexity of the human disease. Future models should involve a combination of neurotoxin and genetic animal models in order to study the progressive neurodegeneration associated with PD. Understanding the mechanisms responsible for this progressive and intrinsic SNc neuronal loss is completely necessary at this point. 


\section{ACKNOWLEDGMENTS}

We thank Dr. Jackson-Lewis for valuable comments and corrections on the manuscript. Javier Blesa was supported by a post-doctoral fellowship from the Spanish Ministry of Education and a post-doctoral fellowship from the Government of Navarra-Euraxess.

\section{REFERENCES}

Akundi, R. S., Huang, Z., Eason, J., Pandya, J. D., Zhi, L., Cass, W. A., et al. (2011). Increased mitochondrial calcium sensitivity and abnormal expression of innate immunity genes precede dopaminergic defects in Pink1-deficient mice. PLoS ONE 6:e16038. doi: 10.1371/journal.pone.0016038

Alam, M., Mayerhofer, A., and Schmidt, W. J. (2004). The neurobehavioral changes induced by bilateral rotenone lesion in medial forebrain bundle of rats are reversed by L-DOPA. Behav. Brain Res. 151, 117-124. doi: 10.1016/j.bbr.2003.08.014

Andres-Mateos, E., Mejias, R., Sasaki, M., Li, X., Lin, B. M., Biskup, S., et al. (2009). Unexpected lack of hypersensitivity in LRRK2 knock-out mice to MPTP (1-methyl-4-phenyl-1,2,3,6-tetrahydropyridine). J. Neurosci. 29, 15846-15850. doi: 10.1523/JNEUROSCI.4357-09.2009

Andres-Mateos, E., Perier, C., Zhang, L., Blanchard-Fillion, B., Greco, T. M., Thomas, B., et al. (2007). DJ-1 gene deletion reveals that DJ-1 is an atypical peroxiredoxin-like peroxidase. Proc. Natl. Acad. Sci. U.S.A. 104, 14807-14812. doi: 10.1073/pnas.0703219104

Baiguera, C., Alghisi, M., Pinna, A., Bellucci, A., De Luca, M. A., Frau, L., et al. (2012). Late-onset Parkinsonism in NFKB/c-Rel-deficient mice. Brain 135, 2750-2765. doi: 10.1093/brain/aws193

Baptista, M. A. S., Dave, K. D., Frasier, M. A., Sherer, T. B., Greeley, M., Beck, M. J., et al. (2013). Loss of leucine-rich repeat kinase 2 (LRRK2) in rats leads to progressive abnormal phenotypes in peripheral organs. PLoS ONE 8:e80705. doi: 10.1371/journal.pone.0080705

Bastías-Candia, S., Di Benedetto, M., D’Addario, C., Candeletti, S., and Romualdi, P. (2013). Combined exposure to agriculture pesticides, paraquat and maneb, induces alterations in the N/OFQ-NOPr and PDYN/KOPr systems in rats: relevance to sporadic Parkinson's disease. Environ. Toxicol. doi: 10.1002/tox.21943 [Epub ahead of print].

Berg, J., Roch, M., Altschüler, J., Winter, C., Schwerk, A., Kurtz, A., et al. (2014). Human adipose-derived mesenchymal stem cells improve motor functions and are neuroprotective in the 6-hydroxydopamine-rat model for parkinson's disease when cultured in monolayer cultures but suppress hippocampal neurogenesis and hippocampal memory functi. Stem Cell Rev. Rep. doi: 10.1007/s12015-014-9551-y [Epub ahead of print].

Berry, C., La Vecchia, C., and Nicotera, P. (2010). Paraquat and Parkinson's disease. Cell Death Differ. 17, 1115-1125. doi: 10.1038/cdd.2009.217

Betarbet, R., Sherer, T. B., MacKenzie, G., Garcia-Osuna, M., Panov, A. V., and Greenamyre, J. T. (2000). Chronic systemic pesticide exposure reproduces features of Parkinson's disease. Nat. Neurosci. 3, 1301-1306. doi: 10.1038/81834

Bezard, E., Imbert, C., Deloire, X., Bioulac, B., and Gross, C. E. (1997). A chronic MPTP model reproducing the slow evolution of Parkinson's disease: evolution of motor symptoms in the monkey. Brain Res. 766, 107-112. doi: 10.1016/S00068993(97)00531-3

Blandini, F., Armentero, M.-T., and Martignoni, E. (2008). The 6-hydroxydopamine model: news from the past. Parkinsonism Relat. Disord. 14(Suppl. 2), S124-S129. doi: 10.1016/j.parkreldis.2008.04.015

Blesa, J., Juri, C., Collantes, M., Peñuelas, I., Prieto, E., Iglesias, E., et al. (2010). Progression of dopaminergic depletion in a model of MPTP-induced Parkinsonism in non-human primates. An (18)F-DOPA and (11)C-DTBZ PET study. Neurobiol. Dis. 38, 456-463. doi: 10.1016/j.nbd.2010.03.006

Blesa, J., Juri, C., Garcia-Cabezas, M. A., Adanez, R., Sanchez-Gonzalez, M. A., Cavada, C., et al. (2011). Inter-hemispheric asymmetry of nigrostriatal dopaminergic lesion: a possible compensatory mechanism in Parkinson's disease. Front. Syst. Neurosci. 5:92. doi: 10.3389/fnsys.2011.00092

Blesa, J., Pifl, C., Sánchez-González, M. A., Juri, C., García-Cabezas, M. A., Adánez, R., et al. (2012). The nigrostriatal system in the presymptomatic and symptomatic stages in the MPTP monkey model: a PET, histological and biochemical study. Neurobiol. Dis. 48, 79-91. doi: 10.1016/j.nbd.2012.05.018

Brehm, N., Bez, F., Carlsson, T., Kern, B., Gispert, S., Auburger, G., et al. (2014). A genetic mouse model of Parkinson's disease shows involuntary movements and increased postsynaptic sensitivity to apomorphine. Mol. Neurobiol. doi: 10.1007/s12035-014-8911-8916 [Epub ahead of print].

Brichta, L., Greengard, P., and Flajolet, M. (2013). Advances in the pharmacological treatment of Parkinson's disease: targeting neurotransmitter systems. Trends Neurosci. 36, 543-554. doi: 10.1016/j.tins.2013.06.003

Brooks, A. I., Chadwick, C. A., Gelbard, H. A., Cory-Slechta, D. A., and Federoff, H. J. (1999). Paraquat elicited neurobehavioral syndrome caused by dopaminergic neuron loss. Brain Res. 823, 1-10. doi: 10.1016/S0006-8993(98)01192-5

Cadet, J. L., Krasnova, I. N., Jayanthi, S., and Lyles, J. (2007). Neurotoxicity of substituted amphetamines: molecular and cellular mechanisms. Neurotox. Res. 11, 183-202. doi: 10.1007/BF03033567

Campos, F. L., Carvalho, M. M., Cristovão, A. C., Je, G., Baltazar, G., Salgado, A. J., et al. (2013). Rodent models of Parkinson's disease: beyond the motor symptomatology. Front. Behav. Neurosci. 7:175. doi: 10.3389/fnbeh.2013.00175

Cannon, J. R., Tapias, V., Na, H. M., Honick, A. S., Drolet, R. E., and Greenamyre, J. T. (2009). A highly reproducible rotenone model of Parkinson's disease. Neurobiol. Dis. 34, 279-290.

Capela, J. P., Carmo, H., Remião, F., Bastos, M. L., Meisel, A., and Carvalho, F. (2009). Molecular and cellular mechanisms of ecstasy-induced neurotoxicity: an overview. Mol. Neurobiol. 39, 210-271. doi: 10.1007/s12035-009-8064-8061

Chege, P. M., and McColl, G. (2014). Caenorhabditis elegans: a model to investigate oxidative stress and metal dyshomeostasis in Parkinson's disease. Front. Aging Neurosci. 6:89. doi: 10.3389/fnagi.2014.00089

Chen, C.-Y., Weng, Y.-H., Chien, K.-Y., Lin, K.-J., Yeh, T.-H., Cheng, Y.-P., et al. (2012). (G2019S) LRRK2 activates MKK4-JNK pathway and causes degeneration of SN dopaminergic neurons in a transgenic mouse model of PD. Cell Death Differ. 19, 1623-1633. doi: 10.1038/cdd.2012.42

Chen, L., Thiruchelvam, M. J., Madura, K., and Richfield, E. K. (2006). Proteasome dysfunction in aged human alpha-synuclein transgenic mice. Neurobiol. Dis. 23, 120-126. doi: 10.1016/j.nbd.2006.02.004

Chiueh, C. C., Markey, S. P., Burns, R. S., Johannessen, J. N., Jacobowitz, D. M., and Kopin, I. J. (1984). Neurochemical and behavioral effects of 1-methyl4-phenyl-1,2,3,6- tetrahydropyridine (MPTP) in rat, guinea pig, and monkey. Psychopharmacol. Bull. 20, 548-553.

Costa, G., Frau, L., Wardas, J., Pinna, A., Plumitallo, A., and Morelli, M. (2013). MPTP-induced dopamine neuron degeneration and glia activation is potentiated in MDMA-pretreated mice. Mov. Disord. 28, 1957-1965. doi: 10.1002/mds. 25646

Dantuma, N. P., and Bott, L. C. (2014). The ubiquitin-proteasome system in neurodegenerative diseases: precipitating factor, yet part of the solution. Front. Mol. Neurosci. 7:70. doi: 10.3389/fnmol.2014.00070

Dauer, W., Kholodilov, N., Vila, M., Trillat, A.-C. C., Goodchild, R., Larsen, K. E., et al. (2002). Resistance of alpha -synuclein null mice to the parkinsonian neurotoxin MPTP. Proc. Natl. Acad. Sci. U.S.A. 99, 14524-14529. doi: $10.1073 /$ pnas. 172514599

Dauer, W., and Przedborski, S. (2003). Parkinson's disease: mechanisms and models. Neuron 39, 889-909. doi: 10.1016/S0896-6273(03)00568-3

Dawson, T. M., Ko, H. S., and Dawson, V. L. (2010). Genetic animal models of Parkinson's disease. Neuron 66, 646-661. doi: 10.1016/j.neuron.2010.04.034

Day, B. J., Patel, M., Calavetta, L., Chang, L. Y., and Stamler, J. S. (1999). A mechanism of paraquat toxicity involving nitric oxide synthase. Proc. Natl. Acad. Sci. U.S.A. 96, 12760-12765. doi: 10.1073/pnas.96.22.12760

Decressac, M., Mattsson, B., Lundblad, M., Weikop, P., and Björklund, A. (2012). Progressive neurodegenerative and behavioural changes induced by AAV-mediated overexpression of $\alpha$-synuclein in midbrain dopamine neurons. Neurobiol. Dis. 45, 939-953. doi: 10.1016/j.nbd.2011.12.013

Dong, Z., Ferger, B., Feldon, J., and Büeler, H. (2002). Overexpression of Parkinson's disease-associated alpha-synucleinA53T by recombinant adeno-associated virus in mice does not increase the vulnerability of dopaminergic neurons to MPTP. J. Neurobiol. 53, 1-10. doi: 10.1002/neu.10094

Drui, G., Carnicella, S., Carcenac, C., Favier, M., Bertrand, A., Boulet, S., et al. (2014). Loss of dopaminergic nigrostriatal neurons accounts for the motivational and affective deficits in Parkinson's disease. Mol. Psychiatry 19, 358-367. doi: 10.1038/mp.2013.3

Dunnett, S. B., and Lelos, M. (2010). Behavioral analysis of motor and non-motor symptoms in rodent models of Parkinson's disease. Prog. Brain Res. 184, 35-51. doi: 10.1016/S0079-6123(10)840038

Dusonchet, J., Kochubey, O., Stafa, K., Young, S. M., Zufferey, R., Moore, D. J., et al. (2011). A rat model of progressive nigral neurodegeneration induced by 
the Parkinson's disease-associated G2019S mutation in LRRK2. J. Neurosci. 31, 907-912. doi: 10.1523/JNEUROSCI.5092-10.2011

Ekstrand, M. I., Terzioglu, M., Galter, D., Zhu, S., Hofstetter, C., Lindqvist, E., et al. (2007). Progressive parkinsonism in mice with respiratory-chaindeficient dopamine neurons. Proc. Natl. Acad. Sci. U.S.A. 104, 1325-1330. doi: 10.1073/pnas.0605208103

El Ayadi, A., and Zigmond, M. J. (2011). Low concentrations of methamphetamine can protect dopaminergic cells against a larger oxidative stress injury: mechanistic study. PLoS ONE 6:e24722. doi: 10.1371/journal.pone.0024722

Exner, N., Lutz, A. K., Haass, C., and Winklhofer, K. F. (2012). Mitochondrial dysfunction in Parkinson's disease: molecular mechanisms and pathophysiological consequences. EMBO J. 31, 3038-3062. doi: 10.1038/emboj.2012.170

Fleming, S. M., Zhu, C., Fernagut, P.-O., Mehta, A., DiCarlo, C. D., Seaman, R. L. et al. (2004). Behavioral and immunohistochemical effects of chronic intravenous and subcutaneous infusions of varying doses of rotenone. Exp. Neurol. 187, 418-429. doi: 10.1016/j.expneurol.2004.01.023

Forno, L. S., Langston, J. W., DeLanney, L. E., Irwin, I., and Ricaurte, G. A. (1986). Locus ceruleus lesions and eosinophilic inclusions in MPTP-treated monkeys. Ann. Neurol. 20, 449-455. doi: 10.1002/ana.410200403

Freire, C., and Koifman, S. (2012). Pesticide exposure and Parkinson's disease: epidemiological evidence of association. Neurotoxicology 33, 947-971. doi: 10.1016/j.neuro.2012.05.011

Friedman, L. G., Lachenmayer, M. L., Wang, J., He, L., Poulose, S. M., Komatsu, M., et al. (2012). Disrupted autophagy leads to dopaminergic axon and dendrite degeneration and promotes presynaptic accumulation of $\alpha$-synuclein and LRRK2 in the brain. J. Neurosci. 32, 7585-7593. doi: 10.1523/JNEUROSCI.5809-11.2012 Gandhi, S., Wood-Kaczmar, A., Yao, Z., Plun-Favreau, H., Deas, E., Klupsch, K., et al. (2009). PINK1-associated Parkinson's disease is caused by neuronal vulnerability to calcium-induced cell death. Mol. Cell 33, 627-638. doi: 10.1016/j.molcel.2009.02.013

Gautier, C. A., Kitada, T., and Shen, J. (2008). Loss of PINK1 causes mitochondrial functional defects and increased sensitivity to oxidative stress. Proc. Natl. Acad. Sci. U.S.A. 105, 11364-11369. doi: 10.1073/pnas.0802076105

Giasson, B. I., Duda, J. E., Quinn, S. M., Zhang, B., Trojanowski, J. Q., and Lee V. M. (2002). Neuronal alpha-synucleinopathy with severe movement disorder in mice expressing A53T human alpha-synuclein. Neuron 34, 521-533. doi: 10.1016/S0896-6273(02)00682-7

Gispert, S., Del Turco, D., Garrett, L., Chen, A., Bernard, D. J., Hamm-Clement, J., et al. (2003). Transgenic mice expressing mutant A53T human alpha-synuclein show neuronal dysfunction in the absence of aggregate formation. Mol. Cell. Neurosci. 24, 419-429. doi: 10.1016/S1044-7431(03)00198-2

Gispert, S., Ricciardi, F., Kurz, A., Azizov, M., Hoepken, H.-H., Becker, D., et al. (2009). Parkinson phenotype in aged PINK1-deficient mice is accompanied by progressive mitochondrial dysfunction in absence of neurodegeneration. PLoS ONE 4:e5777. doi: 10.1371/journal.pone.0005777

Glajch, K. E., Fleming, S. M., Surmeier, D. J., and Osten, P. (2012). Sensorimotor assessment of the unilateral 6-hydroxydopamine mouse model of Parkinson's disease. Behav. Brain Res. 230, 309-316. doi: 10.1016/j.bbr.2011.12.007

Goedert, M., Spillantini, M. G., Del Tredici, K., and Braak, H. (2013). 100 years of Lewy pathology. Nat. Rev. Neurol. 9, 13-24. doi: 10.1038/nrneurol.2012.242

Goldberg, M. S., Fleming, S. M., Palacino, J. J., Cepeda, C., Lam, H. A., Bhatnagar, A., et al. (2003). Parkin-deficient mice exhibit nigrostriatal deficits but not loss of dopaminergic neurons. J. Biol. Chem. 278, 43628-43635. doi: 10.1074/jbc.M308947200

Goldberg, M. S., Pisani, A., Haburcak, M., Vortherms, T. A., Kitada, T., Costa, C., et al. (2005). Nigrostriatal dopaminergic deficits and hypokinesia caused by inactivation of the familial Parkinsonism-linked gene DJ-1. Neuron 45, 489-496. doi: 10.1016/j.neuron.2005.01.041

Gomez-Isla, T., Irizarry, M. C., Mariash, A., Cheung, B., Soto, O., Schrump, S., et al. (2003). Motor dysfunction and gliosis with preserved dopaminergic markers in human alpha-synuclein A30P transgenic mice. Neurobiol. Aging 24, 245-258. doi: 10.1016/S0197-4580(02)00091-X

Gonzalez-Reyes, L. E., Verbitsky, M., Blesa, J., Jackson-Lewis, V., Paredes, D., Tillack, K., et al. (2012). Sonic hedgehog maintains cellular and neurochemical homeostasis in the adult nigrostriatal circuit. Neuron 75, 306-319. doi: 10.1016/j.neuron.2012.05.018

Good, C. H., Hoffman, A. F., Hoffer, B. J., Chefer, V. I., Shippenberg, T. S., Bäckman, C. M., et al. (2011). Impaired nigrostriatal function precedes behavioral deficits in a genetic mitochondrial model of Parkinson's disease. FASEB J. 25, 1333-1344 doi: 10.1096/fj.10-173625

Granado, N., Escobedo, I., O’Shea, E., Colado, I., and Moratalla, R. (2008a). Early loss of dopaminergic terminals in striosomes after MDMA administration to mice. Synapse 62, 80-84. doi: 10.1002/syn.20466

Granado, N., O'Shea, E., Bove, J., Vila, M., Colado, M. I., and Moratalla, R. (2008b). Persistent MDMA-induced dopaminergic neurotoxicity in the striatum and substantia nigra of mice. J. Neurochem. 107, 1102-1112. doi: 10.1111/j.1471-4159.2008.05705.x

Guo, M. (2012). Drosophila as a model to study mitochondrial dysfunction in Parkinson's disease. Cold Spring Harb. Perspect. Med. 2, pii:a009944. doi: 10.1101/cshperspect.a009944

Halliday, G., Herrero, M. T., Murphy, K., McCann, H., Ros-Bernal, F., Barcia, C., et al. (2009). No Lewy pathology in monkeys with over 10 years of severe MPTP Parkinsonism. Mov. Disord. 24, 1519-1523. doi: 10.1002/mds.22481

Haque, M. E., Mount, M. P., Safarpour, F., Abdel-Messih, E., Callaghan, S., Mazerolle, C., et al. (2012). Inactivation of Pink1 gene in vivo sensitizes dopamine-producing neurons to 1-methyl-4-phenyl-1,2,3,6-tetrahydropyridine (MPTP) and can be rescued by autosomal recessive Parkinson disease genes, Parkin or DJ-1. J. Biol. Chem. 287, 23162-23170. doi: 10.1074/jbc.M112.346437

Healy, D. G., Falchi, M., O’Sullivan, S. S., Bonifati, V., Durr, A., Bressman, S., et al. (2008). Phenotype, genotype, and worldwide genetic penetrance of LRRK2associated Parkinson's disease: a case-control study. Lancet. Neurol. 7, 583-590. doi: 10.1016/S1474-4422(08)70117-70110

Heinzen, E. L., Arzimanoglou, A., Brashear, A., Clapcote, S. J., Gurrieri, F., Goldstein, D. B., et al. (2014). Distinct neurological disorders with ATP1A3 mutations. Lancet. Neurol. 13, 503-514. doi: 10.1016/S1474-4422(14)70011-70010

Hennis, M. R., Marvin, M. A., Taylor, C. M., and Goldberg, M. S. (2014). Surprising behavioral and neurochemical enhancements in mice with combined mutations linked to Parkinson's disease. Neurobiol. Dis. 62, 113-123. doi: 10.1016/j.nbd.2013.09.009

Hennis, M. R., Seamans, K. W., Marvin, M. A., Casey, B. H., and Goldberg, M. S. (2013). Behavioral and neurotransmitter abnormalities in mice deficient for Parkin, DJ-1 and superoxide dismutase. PLOS ONE 8:e84894. doi: 10.1371/journal.pone.0084894

Herzig, M. C., Kolly, C., Persohn, E., Theil, D., Schweizer, T., Hafner, T., et al. (2011). LRRK2 protein levels are determined by kinase function and are crucial for kidney and lung homeostasis in mice. Hum. Mol. Genet. 20, 4209-4223. doi: 10.1093/hmg/ddr348

Hess, A., Desiderio, C., and McAuliffe, W. G. (1990). Acute neuropathological changes in the caudate nucleus caused by MPTP and methamphetamine: immunohistochemical studies. J. Neurocytol. 19, 338-342. doi: 10.1007/BF01188403

Hinkle, K. M., Yue, M., Behrouz, B., Dächsel, J. C., Lincoln, S. J., Bowles, E. E., et al. (2012). LRRK2 knockout mice have an intact dopaminergic system but display alterations in exploratory and motor co-ordination behaviors. Mol. Neurodegener. 7:25. doi: 10.1186/1750-1326-725

Howard, C. D., Keefe, K. A., Garris, P. A., and Daberkow, D. P. (2011). Methamphetamine neurotoxicity decreases phasic, but not tonic, dopaminergic signaling in the rat striatum. J. Neurochem. 118, 668-676. doi: 10.1111/j.14714159.2011.07342.x

Hwang, D.-Y., Ardayfio, P., Kang, U. J., Semina, E. V, and Kim, K.-S. (2003). Selective loss of dopaminergic neurons in the substantia nigra of Pitx3-deficient aphakia mice. Brain Res. Mol. Brain Res. 114, 123-131. doi: 10.1016/S0169328X(03)00162-1

Ikeda, M., Kawarabayashi, T., Harigaya, Y., Sasaki, A., Yamada, S., Matsubara, E., etal. (2009). Motor impairment and aberrant production of neurochemicals in human alpha-synuclein A30P+A53T transgenic mice with alphasynuclein pathology. Brain Res. 1250, 232-241. doi: 10.1016/j.brainres.2008. 10.011

Itier, J.-M., Ibanez, P., Mena, M. A., Abbas, N., Cohen-Salmon, C., Bohme, G. A., et al. (2003). Parkin gene inactivation alters behaviour and dopamine neurotransmission in the mouse. Hum. Mol. Genet. 12, 2277-2291. doi: 10.1093/hmg/ddg239

Jackson-Lewis, V., and Przedborski, S. (2007). Protocol for the MPTP mouse model of Parkinson's disease. Nat. Protoc. 2, 141-151. doi: 10.1038/nprot.2006.342

Janezic, S., Threlfell, S., Dodson, P. D., Dowie, M. J., Taylor, T. N., Potgieter, D., et al. (2013). Deficits in dopaminergic transmission precede neuron loss and 
dysfunction in a new Parkinson model. Proc. Natl. Acad. Sci. U.S.A. 110, E4016E4025. doi: 10.1073/pnas.1309143110

Jankovic, J., Chen, S., and Le, W. D. (2005). The role of Nurr1 in the development of dopaminergic neurons and Parkinson's disease. Prog. Neurobiol. 77, 128-138. doi: 10.1016/j.pneurobio.2005.09.001

Jensen, K. F., Olin, J., Haykal-Coates, N., O'Callaghan, J., Miller, D. B., and de Olmos, J. S. (1993). Mapping toxicant-induced nervous system damage with a cupric silver stain: a quantitative analysis of neural degeneration induced by 3,4 methylenedioxymethamphetamine. NIDA Res. Monogr. 136, 133-149; discussion 150-154.

Jiang, C., Wan, X., He, Y., Pan, T., Jankovic, J., and Le, W. (2005). Age-dependent dopaminergic dysfunction in Nurrl knockout mice. Exp. Neurol. 191, 154-162. doi: 10.1016/j.expneurol.2004.08.035

Joselin, A. P., Hewitt, S. J., Callaghan, S. M., Kim, R. H., Chung, Y.-H., Mak, T. W., et al. (2012). ROS-dependent regulation of Parkin and DJ-1 localization during oxidative stress in neurons. Hum. Mol. Genet. 21, 4888-4903. doi: $10.1093 / \mathrm{hmg} / \mathrm{dds} 325$

Kadkhodaei, B., Ito, T., Joodmardi, E., Mattsson, B., Rouillard, C., Carta, M., et al. (2009). Nurrl is required for maintenance of maturing and adult midbrain dopamine neurons. J. Neurosci. 29, 15923-15932. doi: 10.1523/JNEUROSCI. 3910-09.2009

Kara, E., Kiely, A. P., Proukakis, C., Giffin, N., Love, S., Hehir, J., et al. (2014). A 6.4 $\mathrm{Mb}$ duplication of the $\alpha$-synuclein locus causing frontotemporal dementia and parkinsonism: phenotype-genotype correlations. JAMA Neurol. 71, 1162-1171. doi: 10.1001/jamaneurol.2014.994

Kim, R. H., Smith, P. D., Aleyasin, H., Hayley, S., Mount, M. P., Pownall, S., et al. (2005). Hypersensitivity of DJ-1-deficient mice to 1-methyl-4-phenyl-1,2,3,6tetrahydropyrindine (MPTP) and oxidative stress. Proc. Natl. Acad. Sci. U.S.A. 102, 5215-5220. doi: 10.1073/pnas.0501282102

Kirik, D., Annett, L. E., Burger, C., Muzyczka, N., Mandel, R. J., and Björklund, A. (2003). Nigrostriatal alpha-synucleinopathy induced by viral vectormediated overexpression of human alpha-synuclein: a new primate model of Parkinson's disease. Proc. Natl. Acad. Sci. U.S.A. 100, 2884-2889. doi: 10.1073/pnas.0536383100

Kirik, D., Rosenblad, C., Burger, C., Lundberg, C., Johansen, T. E., Muzy czka, N., et al. (2002). Parkinson-like neurodegeneration induced by targeted overexpression of alpha-synuclein in the nigrostriatal system. J. Neurosci. 22, 2780-2791.

Kitada, T., Pisani, A., Karouani, M., Haburcak, M., Martella, G., Tscherter, A., et al. (2009a). Impaired dopamine release and synaptic plasticity in the striatum of parkin-/- mice. J. Neurochem. 110, 613-621. doi: 10.1111/j.14714159.2009.06152.x

Kitada, T., Tong, Y., Gautier, C. A., and Shen, J. (2009b). Absence of nigral degeneration in aged parkin/DJ-1/PINK1 triple knockout mice. J. Neurochem. 111 696-702. doi: 10.1111/j.1471-4159.2009.06350.x

Klein, R. L., King, M. A., Hamby, M. E., and Meyer, E. M. (2002). Dopaminergic cell loss induced by human A30P alpha-synuclein gene transfer to the rat substantia nigra. Hum. Gene Ther. 13, 605-612. doi: 10.1089/1043034025 2837206

Kogan, F. J., Nichols, W. K., and Gibb, J. W. (1976). Influence of methamphetamine on nigral and striatal tyrosine hydroxylase activity and on striatal dopamine levels. Eur. J. Pharmacol. 36, 363-371. doi: 10.1016/0014-2999(76)90090-X

Kowall, N. W., Hantraye, P., Brouillet, E., Beal, M. F., McKee, A. C., and Ferrante, R. J. (2000). MPTP induces alpha-synuclein aggregation in the substantia nigra of baboons. Neuroreport 11, 211-213.

Lachenmayer, M. L., and Yue, Z. (2012). Genetic animal models for evaluating the role of autophagy in etiopathogenesis of Parkinson disease. Autophagy 8 1837-1838. doi: 10.4161/auto.21859

Lam, H. A., Wu, N., Cely, I., Kelly, R. L., Hean, S., Richter, F., et al. (2011). Elevated tonic extracellular dopamine concentration and altered dopamine modulation of synaptic activity precede dopamine loss in the striatum of mice overexpressing human $\alpha$-synuclein. J. Neurosci. Res. 89, 1091-1102. doi: 10.1002/ jnr.22611

Langston, J. W., Ballard, P., Tetrud, J. W., and Irwin, I. (1983). Chronic Parkinsonism in humans due to a product of meperidine-analog synthesis. Science 219, 979-980. doi: $10.1126 /$ science.6823561

Lauwers, E., Bequé, D., Van Laere, K., Nuyts, J., Bormans, G., Mortelmans, L., etal. (2007). Non-invasive imaging of neuropathology in a rat model of alpha-synuclein overexpression. Neurobiol. Aging 28, 248-257. doi: 10.1016/j.neurobiolaging.2005.12.005

Lauwers, E., Debyser, Z., Van Dorpe, J., De Strooper, B., Nuttin, B., and Baekelandt, V. (2003). Neuropathology and neurodegeneration in rodent brain induced by lentiviral vector-mediated overexpression of alpha-synuclein. Brain Pathol. 13, 364-372. doi: 10.1111/j.1750-3639.2003.tb00035.x

Lee, B. D., Shin, J.-H., VanKampen, J., Petrucelli, L., West, A. B., Ko, H. S., et al. (2010). Inhibitors of leucine-rich repeat kinase-2 protect against models of Parkinson's disease. Nat. Med. 16, 998-1000. doi: 10.1038/nm.2199

Li, J., Dani, J. A., and Le, W. (2009a). The role of transcription factor Pitx3 in dopamine neuron development and Parkinson's disease. Curr. Top. Med. Chem. 9, 855-859.

Li, Y., Liu, W., Oo, T. F., Wang, L., Tang, Y., Jackson-Lewis, V., et al. (2009b). Mutant LRRK2(R1441G) BAC transgenic mice recapitulate cardinal features of Parkinson's disease. Nat. Neurosci. 12, 826-828. doi: 10.1038/nn.2349

Li, X., Patel, J. C., Wang, J., Avshalumov, M. V., Nicholson, C., Buxbaum, J. D., et al. (2010). Enhanced striatal dopamine transmission and motor performance with LRRK2 overexpression in mice is eliminated by familial Parkinson's disease mutation G2019S. J. Neurosci. 30, 1788-1797. doi: 10.1523/JNEUROSCI.560409.2010

Lin, X., Parisiadou, L., Gu, X.-L., Wang, L., Shim, H., Sun, L., et al. (2009). Leucinerich repeat kinase 2 regulates the progression of neuropathology induced by Parkinson's-disease-related mutant alpha-synuclein. Neuron 64, 807-827. doi: 10.1016/j.neuron.2009.11.006

Lin, X., Parisiadou, L., Sgobio, C., Liu, G., Yu, J., Sun, L., et al. (2012). Conditional expression of Parkinson's disease-related mutant $\alpha$-synuclein in the midbrain dopaminergic neurons causes progressive neurodegeneration and degradation of transcription factor nuclear receptor related 1. J. Neurosci. 32, 9248-9264. doi: 10.1523/JNEUROSCI.1731-12.2012

Lo Bianco, C., Ridet, J.-L., Schneider, B. L., Deglon, N., and Aebischer, P. (2002). alpha -Synucleinopathy and selective dopaminergic neuron loss in a rat lentiviralbased model of Parkinson's disease. Proc. Natl. Acad. Sci. U.S.A. 99, 10813-10818. doi: 10.1073/pnas.152339799

Lohr, K. M., Bernstein, A. I., Stout, K. A., Dunn, A. R., Lazo, C. R., Alter, S. P., et al. (2014). Increased vesicular monoamine transporter enhances dopamine release and opposes Parkinson disease-related neurodegeneration in vivo. Proc. Natl. Acad. Sci. U.S.A. 111, 9977-9982. doi: 10.1073/pnas.1402134111

Lu, X.-H., Fleming, S. M., Meurers, B., Ackerson, L. C., Mortazavi, F., Lo, V., et al. (2009). Bacterial artificial chromosome transgenic mice expressing a truncated mutant parkin exhibit age-dependent hypokinetic motor deficits, dopaminergic neuron degeneration, and accumulation of proteinase K-resistant alpha-synuclein. J. Neurosci. 29, 1962-1976. doi: 10.1523/JNEUROSCI.535108.2009

Lücking, C. B., Dürr, A., Bonifati, V., Vaughan, J., De Michele, G., Gasser, T., etal. (2000). Association between early-onset Parkinson's disease and mutations in the parkin gene. N. Engl. J. Med. 342, 1560-1567. doi: 10.1056/NEJM200005253422103

Luk, K. C., Kehm, V., Carroll, J., Zhang, B., O’Brien, P., Trojanowski, J. Q., et al. (2012a). Pathological $\alpha$-synuclein transmission initiates Parkinsonlike neurodegeneration in nontransgenic mice. Science 338, 949-953. doi: $10.1126 /$ science. 1227157

Luk, K. C., Kehm, V. M., Zhang, B., O’Brien, P., Trojanowski, J. Q., and Lee, V. M. Y. (2012b). Intracerebral inoculation of pathological $\alpha$-synuclein initiates a rapidly progressive neurodegenerative $\alpha$-synucleinopathy in mice. J. Exp. Med. 209, 975-986. doi: 10.1084/jem.20112457

Luk, K. C., and Lee, V. M.-Y. (2014). Modeling Lewy pathology propagation in Parkinson's disease. Parkinsonism Relat. Disord. 20(Suppl. 1), S85-S87. doi: 10.1016/S1353-8020(13)70022-70021

Maekawa, T., Mori, S., Sasaki, Y., Miyajima, T., Azuma, S., Ohta, E., et al. (2012). The I2020T Leucine-rich repeat kinase 2 transgenic mouse exhibits impaired locomotive ability accompanied by dopaminergic neuron abnormalities. Mol. Neurodegener. 7, 15. doi: 10.1186/1750-1326-715

Manning-Bog, A. B., McCormack, A. L., Li, J., Uversky, V. N., Fink, A. L., and Di Monte, D. A. (2002). The herbicide paraquat causes up-regulation and aggregation of alpha-synuclein in mice: paraquat and alpha-synuclein. J. Biol. Chem. 277, 1641-1644. doi: 10.1074/jbc.C100560200

Martella, G., Platania, P., Vita, D., Sciamanna, G., Cuomo, D., Tassone, A., et al. (2009). Enhanced sensitivity to group II mGlu receptor activation at 
corticostriatal synapses in mice lacking the familial parkinsonism-linked genes PINK1 or Parkin. Exp. Neurol. 215, 388-396. doi: 10.1016/j.expneurol.2008. 11.001

Masliah, E., Rockenstein, E., Veinbergs, I., Mallory, M., Hashimoto, M., Takeda, A., et al. (2000). Dopaminergic loss and inclusion body formation in alpha-synuclein mice: implications for neurodegenerative disorders. Science 287, 1265-1269. doi: 10.1126/science.287.5456.1265

Masuda-Suzukake, M., Nonaka, T., Hosokawa, M., Kubo, M., Shimozawa, A. Akiyama, H., etal. (2014). Pathological alpha-synuclein propagates through neural networks. Acta Neuropathol. Commun. 2, 88. doi: 10.1186/PREACCEPT1296467154135944

Matsui, H., Uemura, N., Yamakado, H., Takeda, S., and Takahashi, R. (2014). Exploring the pathogenetic mechanisms underlying Parkinson's disease in medaka fish. J. Parkinsons. Dis. 4, 301-310. doi: 10.3233/JPD-130289

Matsuoka, Y., Vila, M., Lincoln, S., McCormack, A., Picciano, M., LaFrancois, J., et al. (2001). Lack of nigral pathology in transgenic mice expressing human alpha-synuclein driven by the tyrosine hydroxylase promoter. Neurobiol. Dis. 8 , 535-539. doi: 10.1006/nbdi.2001.0392

McCormack, A. L., Thiruchelvam, M., Manning-Bog, A. B., Thiffault, C., Langston, J. W., Cory-Slechta, D. A., et al. (2002). Environmental risk factors and Parkinson's disease: selective degeneration of nigral dopaminergic neurons caused by the herbicide paraquat. Neurobiol. Dis. 10, 119-127. doi: 10.1006/nbdi. 2002.0507

McDowell, K., and Chesselet, M.-F. (2012). Animal models of the nonmotor features of Parkinson's disease. Neurobiol. Dis. 46, 597-606. doi: 10.1016/j.nbd.2011.12.040

Melrose, H. L., Dächsel, J. C., Behrouz, B., Lincoln, S. J., Yue, M., Hinkle, K. M., et al. (2010). Impaired dopaminergic neurotransmission and microtubule-associated protein tau alterations in human LRRK2 transgenic mice. Neurobiol. Dis. 40, 503-517. doi: 10.1016/j.nbd.2010.07.010

Meredith, G. E., Totterdell, S., Potashkin, J. A., and Surmeier, D. J. (2008). Modeling PD pathogenesis in mice: advantages of a chronic MPTP protocol. Park. Relat Disord 14(Suppl. 2), S112-S115. doi: 10.1016/j.parkreldis.2008.04.012

Miller, G. W. (2007). Paraquat: the red herring of Parkinson's disease research. Toxicol. Sci. 100, 1-2. doi: 10.1093/toxsci/kfm223

Miller, R. M., Kiser, G. L., Kaysser-Kranich, T., Casaceli, C., Colla, E., Lee, M. K., et al. (2007). Wild-type and mutant alpha-synuclein induce a multicomponent gene expression profile consistent with shared pathophysiology in different transgenic mouse models of PD. Exp. Neurol. 204, 421-432. doi: 10.1016/j.expneurol.2006.12.005

Morais, V. A., Haddad, D., Craessaerts, K., De Bock, P.-J., Swerts, J., Vilain, S., et al. (2014). PINK1 loss-of-function mutations affect mitochondrial complex I activity via NdufA10 ubiquinone uncoupling. Science 344, 203-207. doi: $10.1126 /$ science. 1249161

Moratalla, R., Quinn, B., DeLanney, L. E., Irwin, I., Langston, J. W., and Graybiel, A. M. (1992). Differential vulnerability of primate caudate-putamen and striosome-matrix dopamine systems to the neurotoxic effects of 1-methyl-4phenyl-1,2,3,6-tetrahydropyridine. Proc. Natl. Acad. Sci. U.S.A. 89, 3859-3863. doi: 10.1073/pnas.89.9.3859

Morin, N., Jourdain, V. A., and Di Paolo, T. (2014). Modeling dyskinesia in animal models of Parkinson disease. Exp. Neurol. 256, 105-116. doi: 10.1016/j.expneurol.2013.01.024

Morrow, B. A., Roth, R. H., Redmond, D. E., and Elsworth, J. D. (2011). Impact of methamphetamine on dopamine neurons in primates is dependent on age: implications for development of Parkinson's disease. Neuroscience 189, 277-285. doi: 10.1016/j.neuroscience.2011.05.046

Muthane, U., Ramsay, K. A., Jiang, H., Jackson-Lewis, V., Donaldson, D., Fernando, S., et al. (1994). Differences in nigral neuron number and sensitivity to 1-methyl4-phenyl-1,2,3,6-tetrahydropyridine in C57/bl and CD-1 mice. Exp. Neurol. 126, 195-204. doi: 10.1006/exnr.1994.1058

Ness, D., Ren, Z., Gardai, S., Sharpnack, D., Johnson, V. J., Brennan, R. J., et al. (2013). Leucine-rich repeat kinase 2 (LRRK2)-deficient rats exhibit renal tubule injury and perturbations in metabolic and immunological homeostasis. PLoS ONE 8:e66164. doi: 10.1371/journal.pone.0066164

Nieto, M., Gil-Bea, F. J., Dalfó, E., Cuadrado, M., Cabodevilla, F., Sánchez, B., et al. (2006). Increased sensitivity to MPTP in human alpha-synuclein A30P transgenic mice. Neurobiol. Aging 27, 848-856. doi: 10.1016/j.neurobiolaging.2005. 04.010
Nordström, U., Beauvais, G., Ghosh, A., Sasidharan, B. C. P., Lundblad, M., Fuchs, J., et al. (2014). Progressive nigrostriatal terminal dysfunction and degeneration in the engrailed1 heterozygous mouse model of Parkinson's disease. Neurobiol. Dis. doi: 10.1016/j.nbd.2014.09.012

Oaks, A. W., Frankfurt, M., Finkelstein, D. I., and Sidhu, A. (2013). Age-dependent effects of A53T alpha-synuclein on behavior and dopaminergic function. PLoS ONE 8:e60378. doi: 10.1371/journal.pone.0060378

Obeso, J. A., Rodriguez-Oroz, M. C., Stamelou, M., Bhatia, K. P., and Burn, D. J. (2014). The expanding universe of disorders of the basal ganglia. Lancet 384, 523-531. doi: 10.1016/S0140-6736(13)62418-62416

O'Callaghan, J. P., and Miller, D. B. (1994). Neurotoxicity profiles of substituted amphetamines in the C57BL/6J mouse. J. Pharmacol. Exp. Ther. 270, 741-751.

Oliveras-Salvá, M., Macchi, F., Coessens, V., Deleersnijder, A., Gérard, M., Van der Perren, A., et al. (2014). Alpha-synuclein-induced neurodegeneration is exacerbated in PINK1 knockout mice. Neurobiol. Aging 35, 2625-2636. doi: 10.1016/j.neurobiolaging.2014.04.032

Oliveras-Salvá, M., Van der Perren, A., Casadei, N., Stroobants, S., Nuber, S., D'Hooge, R., etal. (2013). rAAV2/7 vector-mediated overexpression of alpha-synuclein in mouse substantia nigra induces protein aggregation and progressive dose-dependent neurodegeneration. Mol. Neurodegener. 8, 44. doi: 10.1186/1750-1326-8-44

Ono, K., Ikemoto, M., Kawarabayashi, T., Ikeda, M., Nishinakagawa, T., Hosokawa, M., et al. (2009). A chemical chaperone, sodium 4-phenylbutyric acid, attenuates the pathogenic potency in human alpha-synuclein A30P + A53T transgenic mice. Parkinsonism Relat. Disord. 15, 649-654. doi: 10.1016/j.parkreldis.2009.03.002

Ottolini, D., Calì, T., Negro, A., and Brini, M. (2013). The Parkinson disease-related protein DJ-1 counteracts mitochondrial impairment induced by the tumour suppressor protein $\mathrm{p} 53$ by enhancing endoplasmic reticulum-mitochondria tethering. Hum. Mol. Genet. 22, 2152-2168. doi: 10.1093/hmg/ddt068

Palacino, J. J., Sagi, D., Goldberg, M. S., Krauss, S., Motz, C., Wacker, M., et al. (2004). Mitochondrial dysfunction and oxidative damage in parkin-deficient mice. J. Biol. Chem. 279, 18614-18622. doi: 10.1074/jbc.M401135200

Pan-Montojo, F., Anichtchik, O., Dening, Y., Knels, L., Pursche, S., Jung, R., et al. (2010). Progression of Parkinson's disease pathology is reproduced by intragastric administration of rotenone in mice. PLOS ONE 5:e8762. doi: 10.1371/journal.pone.0008762

Paumier, K. L., Sukoff Rizzo, S. J., Berger, Z., Chen, Y., Gonzales, C., Kaftan, E., etal. (2013). Behavioral characterization of A53T mice reveals early and late stage deficits related to Parkinson's disease. PLOS ONE 8:e70274. doi: 10.1371/journal.pone.0070274

Perez, F. A., and Palmiter, R. D. (2005). Parkin-deficient mice are not a robust model of parkinsonism. Proc. Natl. Acad. Sci. U.S.A. 102, 2174-2179. doi: 10.1073/pnas.0409598102

Periquet, M., Latouche, M., Lohmann, E., Rawal, N., De Michele, G., Ricard, S., et al. (2003). Parkin mutations are frequent in patients with isolated early-onset parkinsonism. Brain 126, 1271-1278. doi: 10.1093/brain/awg136

Pham, T. T., Giesert, F., Röthig, A., Floss, T., Kallnik, M., Weindl, K., et al. (2010). DJ1-deficient mice show less TH-positive neurons in the ventral tegmental area and exhibit non-motoric behavioural impairments. Genes Brain Behav. 9, 305-317. doi: 10.1111/j.1601-183X.2009.00559.x

Pifl, C., Rajput, A., Reither, H., Blesa, J., Cavada, C., Obeso, J. A, et al. (2014). Is Parkinson's disease a vesicular dopamine storage disorder? Evidence from a study in isolated synaptic vesicles of human and nonhuman primate striatum. J. Neurosci. 34, 8210-8218. doi: 10.1523/JNEUROSCI.5456-13.2014

Porras, G., Li, Q., and Bezard, E. (2012). Modeling Parkinson's disease in primates: the MPTP model. Cold Spring Harb. Perspect. Med. 2, a009308. doi: 10.1101/cshperspect.a009308

Pringsheim, T., Jette, N., Frolkis, A., and Steeves, T. D. L. (2014). The prevalence of Parkinson's disease: a systematic review and meta-analysis. Mov. Disord. 29, 1583-1590. doi: 10.1002/mds.25945

Przedborski, S., Levivier, M., Jiang, H., Ferreira, M., Jackson-Lewis, V., Donaldson, D., et al. (1995). Dose-dependent lesions of the dopaminergic nigrostriatal pathway induced by intrastriatal injection of 6-hydroxydopamine. Neuroscience 67, 631-647. doi: 10.1016/0306-4522(95)00066-R

Purisai, M. G., McCormack, A. L., Langston, W. J., Johnston, L. C., and Di Monte, D. A. (2005). Alpha-synuclein expression in the substantia nigra of MPTP-lesioned non-human primates. Neurobiol. Dis. 20, 898-906. doi: 10.1016/j.nbd.2005.05.028 
Puschmann, A. (2013). Monogenic Parkinson's disease and parkinsonism: clinical phenotypes and frequencies of known mutations. Parkinsonism Relat. Disord. 19, 407-415. doi: 10.1016/j.parkreldis.2013.01.020

Ramonet, D., Daher, J. P. L., Lin, B. M., Stafa, K., Kim, J., Banerjee, R., et al. (2011). Dopaminergic neuronal loss, reduced neurite complexity and autophagic abnormalities in transgenic mice expressing G2019S mutant LRRK2. PLoS ONE 6:e18568. doi: 10.1371/journal.pone.0018568

Rappold, P. M., Cui, M., Chesser, A. S., Tibbett, J., Grima, J. C., Duan, L., et al (2011). Paraquat neurotoxicity is mediated by the dopamine transporter and organic cation transporter-3. Proc. Natl. Acad. Sci. U.S.A. 108, 20766-20771. doi: 10.1073/pnas.1115141108

Rathke-Hartlieb, S., Kahle, P. J., Neumann, M., Ozmen, L., Haid, S., Okochi, M., et al. (2001). Sensitivity to MPTP is not increased in Parkinson's diseaseassociated mutant alpha-synuclein transgenic mice. J. Neurochem. 77, 1181-1184. doi: 10.1046/j.1471-4159.2001.00366.x

Recasens, A., Dehay, B., Bové, J., Carballo-Carbajal, I., Dovero, S., Pérez-Villalba, A., et al. (2014). Lewy body extracts from Parkinson disease brains trigger $\alpha$ synuclein pathology and neurodegeneration in mice and monkeys. Ann. Neurol. 75, 351-362. doi: 10.1002/ana.24066

Rockenstein, E., Mallory, M., Hashimoto, M., Song, D., Shults, C. W., Lang, I., et al. (2002). Differential neuropathological alterations in transgenic mice expressing alpha-synuclein from the platelet-derived growth factor and Thy-1 promoters. J. Neurosci. Res. 68, 568-578. doi: 10.1002/jnr.10231

Rodríguez Díaz, M., Abdala, P., Barroso-Chinea, P., Obeso, J., and GonzalezHernandez, T. (2001). Motor behavioural changes after intracerebroventricular injection of 6-hydroxydopamine in the rat: an animal model of Parkinson's disease. Behav. Brain Res. 122, 79-92. doi: 10.1016/S0166-4328(01)00168-1

Rodriguez-Oroz, M. C., Jahanshahi, M., Krack, P., Litvan, I., Macias, R., Bezard, E., et al. (2009). Initial clinical manifestations of Parkinson's disease: features and pathophysiological mechanisms. Lancet Neurol. 8, 1128-1139. doi: 10.1016/S1474-4422(09)70293-70295

Rousseaux, M. W. C., Marcogliese, P. C., Qu, D., Hewitt, S. J., Seang, S., Kim, R. H., et al. (2012). Progressive dopaminergic cell loss with unilateral-to-bilateral progression in a genetic model of Parkinson disease. Proc. Natl. Acad. Sci. U.S.A. 109, 15918-15923. doi: 10.1073/pnas.1205102109

Rudenko, I. N., and Cookson, M. R. (2014). Heterogeneity of leucine-rich repeat kinase 2 mutations: genetics, mechanisms and therapeutic implications. Neurotherapeutics 4, 738-750. doi: 10.1007/s13311-014-0284-Z

Sacino, A. N., Brooks, M., Thomas, M. A., McKinney, A. B., Lee, S., Regenhardt, R. W., et al. (2014). Intramuscular injection of $\alpha$-synuclein induces CNS $\alpha$-synuclein pathology and a rapid-onset motor phenotype in transgenic mice. Proc. Natl. Acad. Sci. U.S.A. 111, 10732-10737. doi: 10.1073/pnas.1321785111

Sanchez, G., Varaschin, R. K., Büeler, H., Marcogliese, P. C., Park, D. S., and Trudeau, L.-E. (2014). Unaltered striatal dopamine release levels in young Parkin knockout, Pink1 knockout, DJ-1 knockout and LRRK2 R1441G transgenic mice. PLoS ONE 9:e94826. doi: 10.1371/journal.pone.0094826

Sauer, H., and Oertel, W. H. (1994). Progressive degeneration of nigrostriatal dopamine neurons following intrastriatal terminal lesions with 6hydroxydopamine: a combined retrograde tracing and immunocytochemical study in the rat. Neuroscience 59, 401-415. doi: 10.1016/0306-4522(94)90605-X

Scarffe, L. A., Stevens, D. A., Dawson, V. L., and Dawson, T. M. (2014). Parkin and PINK1: much more than mitophagy. Trends Neurosci. 37, 315-324. doi: 10.1016/j.tins.2014.03.004

Schallert, T., Fleming, S. M., Leasure, J. L., Tillerson, J. L., and Bland, S. T. (2000). CNS plasticity and assessment of forelimb sensorimotor outcome in unilateral rat models of stroke, cortical ablation, parkinsonism and spinal cord injury. Neuropharmacology 39, 777-787. doi: 10.1016/S0028-3908(00)00005-8

Schapira, A. H. V., Olanow, C. W., Greenamyre, J. T., and Bezard, E. (2014). Slowing of neurodegeneration in Parkinson's disease and Huntington's disease: future therapeutic perspectives. Lancet 384, 545-555. doi: 10.1016/S01406736(14)61010-61012

Schultheis, P. J., Fleming, S. M., Clippinger, A. K., Lewis, J., Tsunemi, T., Giasson, B., et al. (2013). Atp13a2-deficient mice exhibit neuronal ceroid lipofuscinosis, limited $\alpha$-synuclein accumulation and age-dependent sensorimotor deficits. Hum. Mol. Genet. 22, 2067-2082. doi: 10.1093/hmg/ddt057

Seniuk, N. A., Tatton, W. G., and Greenwood, C. E. (1990). Dose-dependent destruction of the coeruleus-cortical and nigral-striatal projections by MPTP. Brain Res. 527, 7-20. doi: 10.1016/0006-8993(90)91055-L
Sherer, T. B., Kim, J. H., Betarbet, R., and Greenamyre, J. T. (2003). Subcutaneous rotenone exposure causes highly selective dopaminergic degeneration and alphasynuclein aggregation. Exp. Neurol. 179, 9-16. doi: 10.1006/exnr.2002.8072

Shimoji, M., Zhang, L., Mandir, A. S., Dawson, V. L., and Dawson, T. M. (2005). Absence of inclusion body formation in the MPTP mouse model of Parkinson's disease. Brain Res. Mol. Brain Res. 134, 103-108. doi: 10.1016/j. molbrainres.2005.01.012

Singleton, A. B., Farrer, M., Johnson, J., Singleton, A., Hague, S., Kachergus, J., et al. (2003). alpha-Synuclein locus triplication causes Parkinson's disease. Science 302, 841. doi: 10.1126/science. 1090278

Snow, B. J., Vingerhoets, F. J., Langston, J. W., Tetrud, J. W., Sossi, V., and Calne, D. B. (2000). Pattern of dopaminergic loss in the striatum of humans with MPTP induced parkinsonism. J. Neurol. Neurosurg. Psychiatry 68, 313-316. doi: 10.1136/jnnp.68.3.313

Sonsalla, P. K., Jochnowitz, N. D., Zeevalk, G. D., Oostveen, J. A., and Hall, E. D. (1996). Treatment of mice with methamphetamine produces cell loss in the substantia nigra. Brain Res. 738, 172-175. doi: 10.1016/0006-8993(96)00995-X

Sotiriou, E., Vassilatis, D. K., Vila, M., and Stefanis, L. (2010). Selective noradrenergic vulnerability in $\alpha$-synuclein transgenic mice. Neurobiol. Aging 31, 2103-2114. doi: 10.1016/j.neurobiolaging.2008.11.010

Su, X., Federoff, H. J., and Maguire-Zeiss, K. A. (2009). Mutant alpha-synuclein overexpression mediates early proinflammatory activity. Neurotox. Res. 16, $238-$ 254. doi: 10.1007/s12640-009-9053-x

Sziráki, I., Kardos, V., Patthy, M., Pátfalusi, M., and Budai, G. (1994). Methamphetamine protects against MPTP neurotoxicity in C57BL mice. Eur. J. Pharmacol. 251, 311-314. doi: 10.1016/0014-2999(94)90416-2

Takahashi, N., Miner, L. L., Sora, I., Ujike, H., Revay, R. S., Kostic, V., et al. (1997). VMAT2 knockout mice: heterozygotes display reduced amphetamineconditioned reward, enhanced amphetamine locomotion, and enhanced MPTP toxicity. Proc. Natl. Acad. Sci. U.S.A. 94, 9938-9943.

Takahashi, R. N., Rogerio, R., and Zanin, M. (1989). Maneb enhances MPTP neurotoxicity in mice. Res. Commun. Chem. Pathol. Pharmacol. 66, 167-170.

Taylor, T. N., Alter, S. P., Wang, M., Goldstein, D. S., and Miller, G. W. (2014). Reduced vesicular storage of catecholamines causes progressive degeneration in the locus ceruleus. Neuropharmacology 76(Pt A), 97-105. doi: 10.1016/j.neuropharm.2013.08.033

Taylor, T. N., Caudle, W. M., and Miller, G. W. (2011). VMAT2-deficient mice display nigral and extranigral pathology and motor and nonmotor symptoms of Parkinson's disease. Parkinsons Dis. 2011, 124165. doi: 10.4061/2011/ 124165

Taylor, T. N., Greene, J. G., and Miller, G. W. (2010). Behavioral phenotyping of mouse models of Parkinson's disease. Behav. Brain Res. 211, 1-10. doi: 10.1016/j.bbr.2010.03.004

Thiruchelvam, M., Brockel, B. J., Richfield, E. K., Baggs, R. B., and CorySlechta, D. A. (2000). Potentiated and preferential effects of combined paraquat and maneb on nigrostriatal dopamine systems: environmental risk factors for Parkinson's disease? Brain Res. 873, 225-234. doi: 10.1016/S0006-8993(00) 02496-3

Thiruchelvam, M., McCormack, A., Richfield, E. K., Baggs, R. B., Tank, A. W., Di Monte, D. A., etal. (2003). Age-related irreversible progressive nigrostriatal dopaminergic neurotoxicity in the paraquat and maneb model of the Parkinson's disease phenotype. Eur. J. Neurosci. 18, 589-600. doi: 10.1046/j.1460-9568.2003.02781.x

Thiruchelvam, M. J., Powers, J. M., Cory-Slechta, D. A., and Richfield, E. K. (2004). Risk factors for dopaminergic neuron loss in human alpha-synuclein transgenic mice. Eur. J. Neurosci. 19, 845-854. doi: 10.1111/j.0953-816X.2004.03139.x

Thrash, B., Thiruchelvan, K., Ahuja, M., Suppiramaniam, V., and Dhanasekaran, M. (2009). Methamphetamine-induced neurotoxicity: the road to Parkinson's disease. Pharmacol. Rep. 61, 966-977. doi: 10.1016/S1734-1140(09)70158-6

Tieu, K. (2011). A guide to neurotoxic animal models of Parkinson's disease. Cold Spring Harb. Perspect. Med. 1, a009316. doi: 10.1101/cshperspect.a009316

Tong, Y., Pisani, A., Martella, G., Karouani, M., Yamaguchi, H., Pothos, E. N., etal. (2009). R1441C mutation in LRRK2 impairs dopaminergic neurotransmission in mice. Proc. Natl. Acad. Sci. U.S.A. 106, 14622-14627. doi: 10.1073/pnas.0906334106

Tong, Y., Yamaguchi, H., Giaime, E., Boyle, S., Kopan, R., Kelleher, R. J., et al. (2010). Loss of leucine-rich repeat kinase 2 causes impairment of protein degradation pathways, accumulation of alpha-synuclein, and apoptotic cell death in 
aged mice. Proc. Natl. Acad. Sci. U.S.A. 107, 9879-9884. doi: 10.1073/pnas. 1004676107

Trulson, M. E., Cannon, M. S., Faegg, T. S., and Raese, J. D. (1985). Effects of chronic methamphetamine on the nigral-striatal dopamine system in rat brain: tyrosine hydroxylase immunochemistry and quantitative light microscopic studies. Brain Res. Bull. 15, 569-577. doi: 10.1016/0361-9230(85)90206-90200

Tsika, E., Kannan, M., Foo, C. S.-Y., Dikeman, D., Glauser, L., Gellhaar, S., et al. (2014). Conditional expression of Parkinson's disease-related R1441C LRRK2 in midbrain dopaminergic neurons of mice causes nuclear abnormalities without neurodegeneration. Neurobiol. Dis. 71, 345-358. doi: 10.1016/j.nbd.2014. 08.027

Ulusoy, A., Sahin, G., and Kirik, D. (2010). Presynaptic dopaminergic compartment determines the susceptibility to L-DOPA-induced dyskinesia in rats. Proc. Natl. Acad. Sci. U.S.A. 107, 13159-13164. doi: 10.1073/pnas.1003432107

Ungerstedt, U. (1968). 6-Hydroxy-dopamine induced degeneration of central monoamine neurons. Eur. J. Pharmacol. 5, 107-110. doi: 10.1016/00142999(68)90164-7

van den Munckhof, P., Luk, K. C., Ste-Marie, L., Montgomery, J., Blanchet, P. J., Sadikot, A. F., et al. (2003). Pitx3 is required for motor activity and for survival of a subset of midbrain dopaminergic neurons. Development 130, 2535-2542. doi: 10.1242/dev.00464

van der Putten, H., Wiederhold, K. H., Probst, A., Barbieri, S., Mistl, C., Danner, S., et al. (2000). Neuropathology in mice expressing human alpha-synuclein. J. Neurosci. 20, 6021-6029.

Van Rompuy, A.-S., Lobbestael, E., Van der Perren, A., Van den Haute, C., and Baekelandt, V. (2014). Long-term overexpression of human wild-type and T240R mutant Parkin in rat substantia nigra induces progressive dopaminergic neurodegeneration. J. Neuropathol. Exp. Neurol. 73, 159-174. doi: 10.1097/NEN.0000000000000039

Vekrellis, K., Xilouri, M., Emmanouilidou, E., Rideout, H. J., and Stefanis, L. (2011). Pathological roles of $\alpha$-synuclein in neurological disorders. Lancet Neurol. 10 , 1015-1025. doi: 10.1016/S1474-4422(11)70213-70217

Vila, M., Vukosavic, S., Jackson-Lewis, V., Neystat, M., Jakowec, M., and Przedborski, S. (2000). Alpha-synuclein up-regulation in substantia nigra dopaminergic neurons following administration of the parkinsonian toxin MPTP. J. Neurochem. 74, 721-729. doi: 10.1046/j.1471-4159.2000.740721.x

Vincow, E. S., Merrihew, G., Thomas, R. E., Shulman, N. J., Beyer, R. P., MacCoss M. J., et al. (2013). The PINK1-Parkin pathway promotes both mitophagy and selective respiratory chain turnover in vivo. Proc. Natl. Acad. Sci. U.S.A. 110, 6400-6405. doi: 10.1073/pnas.1221132110

Von Coelln, R., Thomas, B., Savitt, J. M., Lim, K. L., Sasaki, M., Hess, E. J., et al. (2004). Loss of locus coeruleus neurons and reduced startle in parkin null mice. Proc. Natl. Acad. Sci. U.S.A. 101, 10744-10749. doi: 10.1073/pnas. 0401297101
Wagner, G. C., Seiden, L. S., and Schuster, C. R. (1979). Methamphetamine-induced changes in brain catecholamines in rats and guinea pigs. Drug Alcohol Depend. 4, 435-438. doi: 10.1016/0376-8716(79)90076-90070

Wakamatsu, M., Ishii, A., Iwata, S., Sakagami, J., Ukai, Y., Ono, M., et al. (2008). Selective loss of nigral dopamine neurons induced by overexpression of truncated human alpha-synuclein in mice. Neurobiol. Aging 29, 574-585. doi: 10.1016/j.neurobiolaging.2006.11.017

Winner, B., Melrose, H. L., Zhao, C., Hinkle, K. M., Yue, M., Kent, C., et al. (2011). Adult neurogenesis and neurite outgrowth are impaired in LRRK2 G2019S mice. Neurobiol. Dis. 41, 706-716. doi: 10.1016/j.nbd.2010.12.008

Xiong, N., Huang, J., Zhang, Z., Zhang, Z., Xiong, J., Liu, X., et al. (2009). Stereotaxical infusion of rotenone: a reliable rodent model for Parkinson's disease. PLoS ONE 4:e7878. doi: 10.1371/journal.pone.0007878

Yang, X., and Xu, Y. (2014). Mutations in the ATP13A2 gene and parkinsonism: a preliminary review. Biomed Res. Int. 2014, 371256. doi: 10.1155/2014/371256

Zhang, H., Duan, C., and Yang, H. (2014). Defective autophagy in Parkinson's disease: lessons from genetics. Mol. Neurobiol. doi: 10.1007/s12035-014-87878785 [Epub ahead of print].

Zhang, L., Le, W., Xie, W., and Dani, J. A. (2012). Age-related changes in dopamine signaling in Nurrl deficient mice as a model of Parkinson's disease. Neurobiol. Aging 33, 1001.e7-1001.e16. doi: 10.1016/j.neurobiolaging.2011.03.022

Zhou, H., Huang, C., Tong, J., Hong, W. C., Liu, Y.-J., and Xia, X.-G. (2011). Temporal expression of mutant LRRK2 in adult rats impairs dopamine reuptake. Int. J. Biol. Sci. 7, 753-761. doi: 10.7150/ijbs.7.753

Zhu, X.-R., Maskri, L., Herold, C., Bader, V., Stichel, C. C., Güntürkün, O., et al. (2007). Non-motor behavioural impairments in parkin-deficient mice. Eur. J. Neurosci. 26, 1902-1911. doi: 10.1111/j.1460-9568.2007.05812.x

Conflict of Interest Statement: The authors declare that the research was conducted in the absence of any commercial or financial relationships that could be construed as a potential conflict of interest.

Received: 20 October 2014; accepted: 27 November 2014; published online: 15 December 2014.

Citation: Blesa J and Przedborski S (2014) Parkinson's disease: animal models and dopaminergic cell vulnerability. Front. Neuroanat. 8:155. doi: 10.3389/fnana.2014. 00155

This article was submitted to the journal Frontiers in Neuroanatomy.

Copyright (C) 2014 Blesa and Przedborski. This is an open-access article distributed under the terms of the Creative Commons Attribution License (CC BY). The use, distribution or reproduction in other forums is permitted, provided the original author(s) or licensor are credited and that the original publication in this journal is cited, in accordance with accepted academic practice. No use, distribution or reproduction is permitted which does not comply with these terms. 